\title{
Outside Mute? Ut, No Wave and Blast First
}

\author{
Ieuan Franklin
}

\section{Introduction: Margins}

This chapter focuses on the all-female no wave band Ut - founded in New York in 1978 by Jacqui Ham, Nina Canal and Sally Young and relocated to London in 1980 - and the similarly uncompromising British independent label Blast First (a sub-label of Mute), to which Ut were signed between 1986 and 1989. Firstly, a proviso - it does not promise to be a comprehensive biography or profile of either the band or label, although I hope to offer some new insights about both. I will not have much scope to discuss the band's recorded output - here I defer to those fanzine writers and music critics, such as Elizabeth Johnson, who have brilliantly articulated the unusual nature of the band's sound, both in concert and on record:

For me, Ut represent one of the most intense musical experiences in the known universe. Are you ready to have your head trip with infinite velocity, sheer and primal ferocity? ... To consider their music a random clang of guitars, erratic rhythms, and screamingly abstract vocals is to commit exorcism on their cohesive dark-sided collage. ('50,000 Reasons' n.d.)

This chapter will instead seek to give a detailed sense of the marginality of Ut in the UK context of being caught between record label disinterest, and a weekly music press that was sometimes guilty of belittling or objectifying female musicians (Reddington 2012: 53). It will explore the relationships of Ut, the band's own label Out Records and Blast First with their 'parent' labels Rough Trade and Mute. It will suggest that Ut had an 'elective affinity' with Mute which was to a limited extent realized when the band signed to Blast First, and also that Ut and Blast First - both having roots in the no wave scene - were too outré for Rough Trade. In the spirit of the recent compilation Sharon Signs to Cherry 
Red: Independent Women 1979-1985 (RPM 2016), documentaries such as Here to Be Heard: The Story of the Slits (2017) and events such as 'Women in Punk and No Wave Film and Music' (held at the Brunswick Club in Bristol on 20 January 2018 and organized by Bristol Experimental Expanded Film), this chapter is also intended as a contribution to the correction of the masculinist narratives often spun around the post-punk scene. Rhian E. Jones has identified a resurgence of interest in post-punk and no wave, and the contribution of women and girls to these scenes in particular. This includes her own writing (2015), which examines Ut, as well as more well-known all-girl bands such as the Slits and the Raincoats. At the time of writing Ut are celebrating the first in a planned series of releases from their remastered back catalogue, through their own (relaunched) record label Out, in partnership with Forte Distribution. This is heartening for fans of the band, and their revival means that Ut are the only band from the original no wave scene still active. The reformation of Ut (c. 2010) and the launch of Paul Smith's Blast First Petite c. 2004 (for titles that Smith likes but that Mute chooses not to release) make this an ideal time to reconsider their unique histories and contributions to noise/art rock.

Ut are a quintessentially marginal band. Byron Coley, who has long recognized their importance, wrote an elegiac entry for Trouser Press magazine after Ut disbanded, noting that the band were 'relatively unknown in the States' and 'deserved far more hep attention than they got' (Coley n.d.). Even their relationship to the no wave scene from which they emerged seems to have been characterized as peripheral, with the fanzine Blog to Comm citing their inclusion in a history of no wave (Masters 2007) as evidence of the book's exhaustive scope, referring to the band as 'outta-the-loopers' ('Three for' 2008). Masters notes, 'Their music bore the mark of New York No Wave but it always felt slightly set apart, and they are rarely cited as an influence in the way peers like Mars and Teenage Jesus and the Jerks have often been' (2007: 153).

When considering their marginal status we must, of course, acknowledge the marginalization of women in rock music (Whiteley 2000; Reddington 2012), as well as the difficulties for an uncompromising band like Ut in finding a label that accepted their identity and ethos. As this chapter will demonstrate, Ut eventually benefitted from what might be termed the cultural 'aftershock' of no wave in the UK by signing to Blast First, yet were still fairly marginal even within their label's roster, due to being crowded out by label and fan interest in fellow US bands associated with the hardcore punk scene, like Sonic Youth, Dinosaur Jr., Butthole Surfers and Big Black. As Jacqui Ham recently recalled, 'We were always sort of last in line' (Ham and Young 2016). 
This chapter posits that Ut may have been marginalized not just because they were sonically abrasive and avant-garde, but because of wider musical and political trends. The no wave music and film scene had offered a significant degree of gender equality. All four bands included on what became the defining document of no wave - the Brian Eno produced compilation album No New York (Antilles 1978) - included women, as did ESG, the Static, the Gynecologists and Ut. Furthermore Nina Canal (a member of The Gynecologists and Ut) played a key role in introducing Eno to the New York art and music scene that year, and can be seen as an unacknowledged midwife to the album. But the UK independent music scene - to which Ut migrated - had not experienced this degree of gender equality, and advances that were made during the punk and post-punk era(s) were quickly undermined and eroded. As Helen Reddington has noted,

After 1979, the whole punk scene fragmented into a 'second wave' of protoskinhead punk ... art-punk bands such as The Raincoats, Gang of Four and Scritti Politti; overtly feminist bands such as Jam Today; and the more mainstream 'new wave' bands such as Elvis Costello and the Attractions and Squeeze. This fragmentation of subcultures had happened before - [Dick] Hebdige documents the breakdown of the Mod subculture into smaller scenes with different taste characteristics. In the case of punk, the separation of the different elements later allowed the 'rock' part to be reclaimed by adolescent males. (2012: 52)

As Mavis Bayton has demonstrated through her analysis of interviews conducted with female musicians during the period 1982/5, loud amplified music was often labelled as 'male' by feminist musicians. Paradoxically, and in stark contrast to the later (early 1990s) riot grrrl subculture in the United States, 'the feminist challenge looked likely to result in retreat from rock and amplified music altogether' in favour of folk, which was considered ideologically safe (Bayton 1993: 185). This meant a narrowing of the already small contingent of women taking up electric instruments. Like other no wave musicians who rejected conventional musical technique, Ut held no truck with such ideological strictures, attempting to break free of ideology and the rigid boundaries and essentialist definitions of gender, genre and discipline altogether.

\section{No wave \& Ut}

Ut formed in 1978 when Nina Canal was introduced to Jacqui Ham and Sally Young, who had grown up together in Connecticut and developed a musical partnership. A formative experience for Ham and Young was seeing Patti Smith 
play with Lenny Kaye at one of their Rock 'n' Rimbaud performances in 1973. Although inspired by Smith and her debut Horses (Arista 1975), Ham and Young came to distance themselves from her perceived reverence for rock - Ham states that 'we were trying to blow it [rock] apart' (Ham and Young 2016). No wave was built upon these impulses of rejection and resistance to commodification; it literally and rhetorically negated 'new wave', which was generally felt to be a bogus label invented by the music industry to sanitize punk. Like 'punk' itself, it was a convenient umbrella term or label for a gaggle of disparate bands and artists, many of whom chafed at the imposition of the label, despite the interconnected and incestuous nature of the scene. One thing that set Ut apart from their peers was the fluidity of roles within the group: they all swapped instruments and vocal duties during live performances and recordings. Canal recalls,

None of us were particularly interested in being just the guitarist or just the drummer or just this or that ... each of us felt we wanted to encompass as much as possible, as much possibility and variation as could be imagined. No limits, no restrictions. We wanted it all, we were bold, we reached beyond. ... Maybe we were just greedy about it, in a good way. We decided that we were each going to have turns being dustbin collector and dictator. We would each get to dictate. If we wrote a song and wanted to say how this would be and that would be, we would get that opportunity, but then we would also have to follow everyone else's orders at other times. So that's how we figured we would have the most fun and create the most challenging environment. We had nicknames for each other's dictator personalities, which was hilarious. (Canal n.d.)

As a band that did not self-identify as feminist, but which did reject inter-band hierarchies, Ut's 'rotating dictatorship' represents an interesting alternative to the tendency for feminist bands to embrace 'collectivism and co-operation instead of competitive individualism; participative democracy and equality instead of hierarchy' (Bayton 1993: 179). Musically, it meant that their interplay locked together in unique combinations, giving their work a variety and a heightened quality often missing from that of their peers. Each musician could play from multiple perspectives in a way that enriched the song. Ut developed a certain reputation for intriguing and intense live shows, also characterized by the longeurs of instrument-swapping during which they refused to connote 'to-belooked-at-ness', to allude to Laura Mulvey's concept of 'the male gaze' (1989):

There is an alchemy in electric guitars played in a certain way by those who know how: it is connected to a kind of physics in which harmonics clash and squeeze 
one another under pressure. ... When a song ends, they chafe against the state of being caught in light, of being watched, of having no way of saying, No, it's not us that are the object of attention. So we share with them the burden of that other claustrophobia, the smog of light in which society touches and retouches itself. Until they start again. (Hodgkinson 2016: 152. Emphasis in original)

The no wave scene of the late 1970s was a prime example of artistic crossfertilization and communal living, in which bands formed in the blink of an eye and which saw a real fluidity in roles as filmmakers, musicians and artists 'swapped places', as Young explains: 'It came from that attitude that we could do anything, it was almost like a new renaissance ... there's no reason why you should have to [just] be a musician or an artist' (Ham and Young 2016).

Many no wave bands found New York alternative arts institutions such as Artists Space or White Columns more accommodating venues than punkoriented nightclubs, while at the same time many art school graduates 'turned to music because galleries and museums seemed impenetrable and stale, whereas the music scene was open to newcomers experimenting with form' (Halasz 2015: 97). Numerous visual artists based in the downtown and East Village actively participated in this scene, such as Jean-Michel Basquiat (who founded the group Gray), Barbara Ess, Nina Canal, Robert Longo (who was in the band Menthol Wars and designed sleeves for Theoretical Girls) and Robert Appleton (who was in the Gynaecologists with Canal) (Molon and Diederichsen 2007: 14).

One common factor between the United Kingdom and the United States was the influence of art colleges on the post-punk scene. Sarah Lowndes notes that Canal had attended Hornsey College of Art, as had Graham Lewis (who later formed the band Wire) and Raincoats bassist Gina Birch (2016: 96). The availability of squats and cheap accommodation (loft-spaces in the case of New York) was also a common factor, as was social deprivation and urban decay. Ham observed of New York during the late 1970s that,

Rent was so cheap that you didn't have to work ... I think it was one of the Bush Tetras who said, 'No-one worked ...' You did, but you hardly worked at all $\ldots$ and some people just stayed on people's floors. We had a rehearsal place for $\$ 25$ a month, in a back room off a landscape architect's [house], really in the ghetto, there were transom windows and you could see the rats go by. But it was a fantastic place to play ... we'd roll our amps in there. And we rehearsed in a loft at the end of the street, looking at the World Trade Center. ... But the atmosphere in New York was changing - by ' 81 . There were only three clubs 
you could play, unless you could pass as a normal rock band, which we couldn't. (Ham and Young 2016)

Ut recorded a single in New York's Sorcerer Sound studio, produced by the late Charles Ball and intended for release on his Lust/Unlust label. But, sadly, the single was aborted:

Unfortunately with us, our record was made, our cover was made, we had a release party, and he [Ball] went AWOL and it never came out. It was really tragic for us - that was July 1980. (Ham and Young 2016)

On the promise of a support slot with the Fall, a band Ut strongly identified with, and the opportunity of recording time with John Loder (best known for founding Southern Studios and working for Crass Records), Ut decamped to London.

The aforementioned No New York had been compiled and produced by an Englishman, Brian Eno. Yet the no wave scene never really seemed to take root in the UK, despite the best efforts of tiny labels like Fetish. ${ }^{1}$ Richard King has noted that the Rough Trade shop was buying in all the new hip no wave releases from 99 Records and Lust/Unlust in the post-punk period and he ventures the opinion that 'If Rough Trade had an equivalent anywhere in the world it was 99, a record and badge shop that under the direction of its owner Ed Bahlman started releasing records by Liquid Liquid, ESG, Bush Tetras and Glenn Branca' (2012: 126).

However, it is worth noting that Rough Trade certainly did not seek to sign no wave bands or exponents, passing up the opportunity to sign Ut (in fact, as 99 Records had done previously). Instead Ut started their own Out label, selfreleasing their material through a manufacturing and distribution $(M \& D)$ deal with Rough Trade, which gave bands a set period of time to sell records to recover the costs of pressing records and artwork. After a live mini-album (Ut Live, Out 1982), Ut released their studio debut album Conviction (Out 1985). Thereafter, they signed with Blast First, who created another pressing of the album and released Early Live Life in 1987, a live retrospective recorded at various shows in New York and England between 1979 and 1985.

Why did it take so long for Ut to release a full-length album? According to Ham they had always been 'a difficult proposition' for a label, with their uncompromisingly discordant sound and their refusal to adopt a marketable

Fetish released records by 8-Eyed Spy (a group formed by Lydia Lunch), Bush Tetras and Snatch (Patti Palladin and Judy Nylon) in 1980 and 1981. 
band image or identity (Ham and Young 2016). Canal has acknowledged that Rough Trade's M\&D deals were a 'fantastic opportunity' for those bands deemed by Rough Trade as worthy of taking a punt on (Canal n.d.). But it is also interesting to consider whether bands were held at one remove through this process, which may shed light on the disjuncture between the types of music sold in the Rough Trade shop or enjoyed by the warehouse staff, and the types of music signed to the label.

By contrast, Mute had always maintained an interesting balance between the indigenous electro-pop of Depeche Mode and Erasure, and ear-splitting German noise brutalists like Einsturzende Neubaten and DAF, with the commercial success of the former funding more experimental - and often archival - releases. Moreover, as the 1970s drew to a close some no wave musicians had already begun to gravitate towards the more gothic and electronic sound (sometimes referred to as 'dark wave') of Mute artists and bands such as the Normal, Robert Rental and Throbbing Gristle. ${ }^{2}$

On a personal level, Miller had a genial and casual air, which belied the extreme nature of some of the music released on his label. The typically forthright view of Blast First's press officer Liz Naylor, who had been a prolific contributor to Manchester punk fanzines and a Rough Trade staffer, was that 'Daniel was nice: he wasn't intimidating in that kind of Cambridge way that Geoff [Travis, founder of Rough Trade] had' (King 2012, 290). According to Ham, Rough Trade 'did not get New York, they did not get the [urban aesthetic] or Nick Cave's thing. And ... Daniel, with his "Warm Leatherette" [single], he was into [the] urban and strange. He got the ... Velvet Underground, the Birthday Party, Iggy Pop ... Daniel was open to outsiders, he was the home for our kind, you know' (Ham and Young 2016).

Ut had encountered Miller and Mute soon after arriving in London in August 1981 through the close friendships they had already struck up with Rough Trade's Scott Piering and Richard Scott. Piering, a sociology graduate from the University of California who headed up Rough Trade's promotions department, had brokered Ut's connection with the Fall by passing on a tape of their music to singer Mark E. Smith when on tour with them in America. Ut actually rehearsed in the basement of Mute's early home, in Seymour Place, as well as at Rough Trade's original premises on Ladbroke Grove. But as they didn't really fit in

\footnotetext{
This is particularly evident on Dark Day's 1979 Lust/Unlust single 'Hands in the Dark' / 'Invisible Man', a group that at that time comprised Robin Crutchfield (ex-DNA), Nancy Arlen (ex-Mars) and Nina Canal.
} 
musically with Mute's roster at the time they assumed that Mute would never sign them. When Paul Smith later brought his Blast First imprint to Mute in 1986, Ut were given an opportunity to become a member (albeit again 'once removed') of the Mute family.

\section{Nothing short of total war}

In 1985, after his partners in the video/record label Doublevision (Stephen Mallinder and Richard H. Kirk of Cabaret Voltaire) vetoed a release on their label of Sonic Youth's Bad Moon Rising for the same reason that Ut assumed Mute would reject them (too rock'n'roll), Smith shopped around the tape to a multitude of labels. Eventually Peter Walmsley of Rough Trade, half in exasperation due to Smith's relentless proselytizing, offered to release it if Smith obtained the rights, which, King has termed 'among the last of the offthe-street Rough Trade deals' (2012: 284). To do so Smith needed to establish an imprint/label, hence Blast First was born. Sonic Youth biographer Stevie Chick summarized the contribution that Blast First would ultimately make to the UK independent music scene: 'In the years that followed, the label would build a formidable roster of groups from the American underground, sating British audiences unmoved by their country's more tepid local produce, hungering for the profane avant chaos the Blast First label reliably offered' (2009: 99).

Blast First's roster, which included the Butthole Surfers, Big Black and Band of Susans, was the 'vortex for trans-Atlantic energies' (Stubbs 2009) which would provide an anarchic corrective to some of the anaemic excesses of British indie music during the mid-1980s (King 2012: 297-98). In fact, Blast First soon developed a reputation for subversion and provocation that mirrored many of the bands on their roster. To coincide with their UK tour in 1985, Sonic Youth sought to release 'Halloween' b/w 'Flower' as a 12" single in the UK on Blast First, but soon ran into trouble with Rough Trade regarding the artwork, supplied by the band. The sleeve featured a Xeroxed image of a topless woman from a Puerto Rican calendar, and some staff working in the Rough Trade distribution, wholesale and export sections initially refused to handle the single (King 2012: 285). Although this issue was eventually resolved after a meeting with the band, the incident did cause friction between Blast First and Rough Trade, and it was no coincidence that in 1986 Blast First parted ways with Rough Trade (this 
relationship had been established less than a year previously) and made its home in Harrow Road as a sub-label of Mute. ${ }^{3}$

Rough Trade's internal debate and action over the Sonic Youth artwork was interpreted by some as evidence of how it differed from mainstream record labels due to its internal democracy (Hesmondhalgh 1997: 268), while others regarded the label as having flirted with censorship over its initial handling of the issue. The controversy provoked Claude Bessy, an iconoclastic French fanzine writer who worked in Rough Trade's Promotions Department, to clamber onstage moments before Sonic Youth's performance at the University of London, 30 October 1985, and issue an impassioned tirade:

In these days of AIDS: and Ethiopia ... you would think a major alternative record company would have better things to do than worry about the shape of our bodies. So, I thought I'd let you know, next time you go and buy a record, and you're think you're really alternative and groovy, remember it's just like the other side, except it's a bit stranger. There's no fucking culture there, you know. There's just as much censorship. (Chick 2009: 111)

Listeners who tolerated the relentless racket of the vinyl edition of the 1988 Blast First compilation Nothing Short of Total War right until the end were rewarded with a looped extract from Bessy's tirade, endlessly repeating on the locked groove. Many fans of Ut would discover the band due to the inclusion of two of their tracks ('Fire in Philly' and 'Evangelist') on this compilation. To quote from Pat Naylor's press release (reproduced on the album's inner sleeve), 'Hands up who bought it for the Ut tracks? Let's face it, most will shell out for the likes of Sonic Youth, Buttholes or Big Black ... and in the process you get to hear stuff you were too ignorant to open your ears to'.

Nothing Short of Total War, as the title suggests, is perhaps the closest thing to an anti-compilation (of anti-music), denying the listener an easily identifiable position or identity, to paraphrase Dave Laing (Street 1992: 315). The CD version is encoded as a single track, so that there is no option to skip between songs. The LP version features no track listing or liner credits, in favour of showcasing the Savage Pencil (the nom de plume of the artist and music journalist Edwin Pouncey) cover art. The inner sleeve features a text and image collage including extracts from the Wyndham Lewis magazine Blast, the short-lived literary magazine of the Vorticist movement in Britain from which the label took

3 Daniel Miller had expressed an interest in the British 'noise rock' band Head of David, signed to Blast First, after hearing them on John Peel's radio show. 
its name. This approach transcended the limitations and hierarchies of the conventional sampler, providing a unique way of getting to know the label and its ethos. Steve Albini, who produced Ut's Griller (Blast First 1989), has given the following judgement about Nothing Short of Total War:

The best thing about this comp was hearing all these great bands presented unannounced, on a single plane with no commentary or critical perspective. Ut ... Band of Susans, Head of David ... the ' 80 s had so many great, distinctive bands that a lot of them were obscured by both the personalization (mini-starmaking I mean) and the obsession with movements and micro-movements. This was one of the only pure-music listening experiences you could have in that environment. (2015)

\section{Conclusion}

Ut's contributions stood out as succinct and mature, shorn of the hierarchies, cliques and pigeonholing that Albini refers to. As we have already seen, the period in which Ut formed and developed saw styles that once would have fallen under the large umbrella of punk earn more specific labels like power pop, art rock, no wave, new wave and hardcore. As Mary Wolf has remarked,

The proliferation of sub-genres was accompanied by the segmentation of punk audiences. This aesthetic explosion and the codification that accompanied it had important ramifications for women's role in punk because the various subgenres in punk became increasingly gendered over time. (2007: 288)

This fragmentation is evident when examining Blast First, which had a roster of hardcore bands schooled in the most aggressive strains of psychedelia, industrial music, heavy metal and no wave. Many 'arty' punk scenes in which women had hitherto thrived became arenas of aggressive hyper-masculinity with the arrival of hardcore in the 1980s. Yet although in some ways Ut were an atypical act for Blast First, the band also had a hard-edged sound, and felt a kinship with other acts (many of whom were compatriots) on the label. Ham states:

We were very happy to be on a label ... and, for a while, it was great. The crowd that he [Smith] got - Sonic Youth, us, Head of David, Big Black, Butthole Surfers, Big Stick, I mean it was great. And we really did fit in with that whole scene ... it was wonderful. But we had to wait for him to do Sonic Youth, so we were always sort of last in line ... he said to us 'You're ...' And the thing is he had problems selling us. (Ham and Young 2016) 
It is commonly believed that the anti-establishment stance of punk opened up possibilities for female musicians, who had hitherto been treated like outsiders in a male-dominated industry. But in fact even in punk women's progress was limited, which is something that has only belatedly received acknowledgement (Wolf 2007: 285). By the mid-to-late 1980s - when Ut released the majority of their work - post-punk experimentalism seemed to have run its course. In retrospect, for female musicians this was a fallow period sandwiched between no wave/post-punk and riot grrrl, the highly publicized feminist DIY punk movement that emerged from the North-West of America in the early 1990s.

The uncompromising nature of Ut's sound (influenced by free jazz and the Velvet Underground) would circumscribe their treatment by the UK music press throughout the 1980s. While (predominantly male) critics embraced shepunk innovators like the Slits and the Raincoats, they ignored Ut (Mamone 1999). Perhaps this can partly be explained by the fact that they were constantly attributed the label of no wave, a scene which divided critics, as some regarded the music as downright unlistenable. Nina Canal has suggested that this ambivalence was also a consequence of the intensity of their music and live performances:

If you're a woman ... and you show deep emotion, people say you're neurotic or ... hysterical. ... And if you're a guy, you're 'cool'. ... We didn't want to dress up as sex kittens to get that attention. That was not where our interest lay. At that time, most girl bands were, in some form or another, trying to use that in an attentiongetting way. We wanted our music to get the attention and we were trying to do something substantial, real, deep. (Canal n.d.)

In addition, as previously mentioned, Ut were not an avowedly feminist band like the similarly pioneering all-female Portland punk group Neo Boys (active from 1978 to 1983). To quote music journalist Jordan Mamone:

Ut's harder, more technical approach had subversively smashed women-in-rock stereotypes without even acknowledging feminism or gender. That the band's decade-plus lifespan outlasted the brief careers of the Delta5, the Au Pairs and LiLiPUT proves that girl power is no match for grown-up artistic conviction. (1999)

Byron Coley has opined that the initial riot grrrl bands - such as Bratmobile and Bikini Kill - were 'more similar to No Wave bands like Ut ... than anything else you could name' (2014). But Jacqui Ham and Sally Young have felt more kinship with bands that have articulated and exuded urban alienation and unease - 
Joy Division, Birthday Party, Einsturzende Neubauten, Slint and Nirvana. They regard Kurt Cobain a kindred spirit, who would have been welcome to join their band (Ham and Young 2016). He had been a fan of the riot grrrl bands, and wrote touchingly about how his life had been changed by hearing Ut's closest UK analogue, the Raincoats. Yet Cobain, who was keen to voice his support for numerous obscure bands, seemingly never heard Ut, despite his close connections with Ut-proselytizers such as Thurston Moore, Kim Gordon, Steve Albini and Everett True. Despite having a close relationship to such US underground luminaries in art and music, as well as UK industry insiders like Scott Piering, it was Ut - rather than their label-mates, who nearly all moved on from Blast First to major labels - who remained quintessential outsiders, playing 'outsider music'.

\section{References}

'50,000 Reasons: Ut' (n.d.), Ut/Music. Available online: http://www.utmusic.net/50000reasons-ut (accessed 17 April 2018).

Albini, S. (2015), 'Nothing Short of Total War', Electrical Audio, 27 July. Available online: http://www.electricalaudio.com/phpBB3/viewtopic.php?f=4\&t=15433\&start=20 (accessed 5 August 2017).

Bayton, M. (1993), 'Feminist Musical Practice: Problems and Contradictions', in T. Bennett, S. Frith, L. Grossberg, J. Shepherd and G. Turner (eds), Rock and Popular Music: Politics, Policies, Institutions, 177-92, Oxford: Taylor and Francis.

Canal, N. (n.d.), 'Interview with Nina Canal'. Available online: http://web.archive.org/ web/19991105160118/http://www.geocities.com:80/SunsetStrip/Disco/6402/nina2. html (accessed 16 April 2018).

Chick, S. (2009), Psychic Confusion: The Sonic Youth Story, London: Omnibus Press.

Coley, B. (2014), 'Iconic Music Critic Byron Coley Looks for Traces of NYC's No Wave in Contemporary Culture', Huck Magazine, 14 November. Available online: http:// www.huckmagazine.com/perspectives/opinion-perspectives/byron-coley-no-wave/ (accessed 15 August 2017).

Coley, B. (n.d.), 'Ut', Trouser Press. Available online: http://www.trouserpress.com/entry. php?a=ut (accessed 16 April 2018).

Halasz, J. R. (2015), The Bohemian Ethos: Questioning Work and Making a Scene on the Lower East Side, London: Routledge.

Ham, J., and S. Young (2016), Joint interview with the author, London, 24 June.

Here to be Heard: The Story of the Slits (2017), [Film] Dir. William E. Badgley, UK: Head Gear Films, Metrol Technology, Molasses Manifesto, Moveihouse Entertainment. 
Hesmondhalgh, D. (1997), 'Post-Punk's Attempt to Democratise the Music Industry: The Success and Failure of Rough Trade', Popular Music, 16 (3): 255-74.

Hodgkinson, T. (2016), Music and the Myth of Wholeness: Toward a New Aesthetic Paradigm, Cambridge: MIT Press.

Jones, R. (2015), 'Post-Punk: Raw, Female Sound', in J. Downes (ed.), Women Make Noise: Girl Bands from Motown to the Modern, 187-214, London: Aurora Metro Books.

King, R. (2012), How Soon Is Now?: The Madmen and Mavericks Who Made Independent Music 1975-2005, London: Faber \& Faber.

Lowndes, S. (2016), The DIY Movement in Art, Music and Publishing: Subjugated Knowledges, London: Routledge.

Mamone, J. N. (1999), 'I’m Your Fan: Ut', CMJ New Music Report, 25 January. Available online: https://plus.google.com/s/\%23UtArchives/posts (accessed 20th April 2018).

Masters, M. (2007), No Wave, London: Black Dog.

Molon, D., and D. Diederichsen (2007), Sympathy for the Devil: Art and Rock and Roll Since 1967, London: Yale University Press.

Mulvey, L. (1989), 'Visual Pleasure and Narrative Cinema', Visual and Other Pleasures, 14-26, London: Palgrave Macmillan UK.

Reddington, H. (2012), The Lost Women of Rock Music: Female Musicians of the Punk Era, 2nd edn, Sheffield: Equinox Publishing Ltd.

Street, J. (1992), 'Shock Waves: The Authoritative Response to Popular Music', in D. Strinati and S. Wagg (eds), Come on Down?: Popular Media Culture in Post-War Britain, 302-8, London: Routledge.

Stubbs, D. (2009), 'Sonic Youth And the Blast First Axis', The Wire, 12 February. Available online: http://www.rocksbackpages.com/Library/Article/sonic-youth-andthe-blast-first-axis (accessed 15th August 2017).

'Three for the Price of None!' (2008), Blog to Comm, 13 April. Available online: http:// black2com.blogspot.co.uk/2008_04_01_archive.html (accessed 16 April 2018).

Whiteley, S. (2000), Women and Popular Music: Sexuality, Identity, and Subjectivity, London: Psychology Press.

Wolf, M. M. (2007), “We Accept You, One of Us?”: Punk Rock, Community, and Individualism in an Uncertain Era, 1974-1985'. Available online: https://cdr.lib.unc. edu/record/uuid:9da5d840-fe83-4988-82ac-5f78a9e73c84 (accessed 5 May 2017). 
